Abstracta Iranica Abstracta Iranica

Revue bibliographique pour le domaine irano-aryen

Volume 27 | 2006

Comptes rendus des publications de 2004

\title{
Romān-hā-ye mo'āṣer-e fārsī. Tehrān, Nīlūfar, 1382 (tomes 1 et 2). [Les romans persans contemporains]
}

\author{
Julie Duvigneau
}

\section{OpenEdition}

1 Journals

Édition électronique

URL : http://journals.openedition.org/abstractairanica/6522

DOI : $10.4000 /$ abstractairanica.6522

ISSN : 1961-960X

\section{Éditeur :}

CNRS (UMR 7528 Mondes iraniens et indiens), Éditions de l'IFRI

\section{Édition imprimée}

Date de publication : 15 mai 2006

ISSN : 0240-8910

\section{Référence électronique}

Julie Duvigneau, «Romān-hā-ye mo'āșer-e fārsī. Tehrān, Nïlūfar, 1382 (tomes 1 et 2). [Les romans persans contemporains] », Abstracta Iranica [En ligne], Volume 27 | 2006, document 325, mis en ligne le 02 janvier 2007, consulté le 25 septembre 2020. URL : http://journals.openedition.org/ abstractairanica/6522 ; DOI : https://doi.org/10.4000/abstractairanica.6522

Ce document a été généré automatiquement le 25 septembre 2020.

Tous droits réservés 


\title{
Romān-hā-ye mo'āṣer-e fārsī. Tehrān, Nīlüfar, 1382 (tomes 1 et 2). [Les romans persans contemporains]
}

\author{
Julie Duvigneau
}

1 Par ce premier ouvrage d'un série de trois (dont deux seulement sont parus à ce jour), l'A. entend apporter de l'aide aux chercheurs en littérature en présentant les romans persans les plus importants depuis La chouette aveugle de Hedāyat. L'activité littéraire $\mathrm{du} 20^{\mathrm{e}} \mathrm{s}$. est divisée en trois générations; le premier tome est consacré chronologiquement aux premières œuvres romanesques des auteurs de la première et de la deuxième génération (de 1936 à 1995), le second approfondit en prenant des œuvres plus tardives des auteurs déjà présentés et en en rajoutant d'autres (de 1946 à 2000).

2 Le troisième livre, à paraître, présentera des écrivains ayant publié leur premier roman après 1979.

3 Chaque roman fait l'objet d'une étude en quatre parties : une fiche technique (contenu, structure, situation spatio-temporelle, noms des personnages, genre littéraire et point de vue), un résumé critique (succinct étant donné le volume de l'ouvrage), le synopsis de l'intrigue et enfin, des morceaux choisis.

4 Cette série d'ouvrages nous semble constituer un outil très précieux pour la connaissance de la littérature persane. 
INDEX

Thèmes : 11.1.2. Littérature persane moderne nompropre Sādeq Hedāyat

\section{AUTEURS}

JULIE DUVIGNEAU

Paris 